\title{
Explaining the Deterrence Effect of Human Rights Prosecutions for Transitional Countries
}

Mass human rights violations are among the most pressing international problems facing policy makers today. Many more people were killed by their own governments in the twentieth century than the combat deaths of all the wars combined. ${ }^{1}$ The early years of the twenty-first century give no indication that this trend is abating. Yet, while the academic literature on the causes of war is well developed, the literature on causes of human rights violations is still relatively new. Because human rights violations are so prevalent, the discussion of how to prevent or diminish repression has important theoretical and policy implications.

Human rights prosecutions have been the major policy innovation of the late twentieth century designed to diminish human rights violations. ${ }^{2}$ The justification for such trials has rarely been merely retributive; the purpose has not been only to punish perpetrators, but also to use accountability to deter future violations. ${ }^{3}$ This deterrence hypothesis states that increases in the probability of prosecution should diminish repression. But until now, data on human right trials has not existed to be able to test the deterrence hypothesis. In this article, we use our new dataset on domestic and international human rights prosecutions to test the deterrence argument, and to generate new arguments about the causes of and remedies for repression. We also link the argument to a broader debate in international relations about the role of enforcement for compliance with international rules, and provide additional arguments about the mechanisms

\footnotetext{
${ }^{1}$ Rudolph Rummel (1994) estimates that the death toll from governmental mass murder of civilians was more than four times the battle dead for this century's international and civil wars. This estimate was based on data up to 1987, before the major episodes of mass murder in the Balkans and Rwanda in the mid-1990s.

${ }^{2}$ Ellen L. Lutz and Caitlin Reiger (2008) document 43 prosecutions of heads of state for human rights crimes between January 1990 and June 2008.

${ }^{3}$ See Akhaven (2001). President Alfonsin (1996:87) said that the justification for the trials in Argentina was "not mainly punishment, but prevention: to avoid that this could happen again." The Deputy Prosecutor of the International Criminal Court (ICC) said that "to deter other people from committing crimes" was a principle goal of the court (Interview, Fatou Bensouda, The Hague, November 10, 2008).
} 
through which prosecutions exercise their deterrence effect. The practical significance of such research is great: if the possibility of prosecutions can diminish repression, such knowledge could inform choices that policymakers are currently making around the world about whether or not to use human rights trials.

Since the 1980s, states are increasingly addressing past human rights violations using multiple mechanisms including trials, truth commissions, reparations, vetting, museums and other memory sites, archives, and oral history projects (Bassiouni, 2002, Hayner, 2002, Jelin et al., 2003, Kritz, 1995, McAdams, 1997). This paper focuses on the most important of these mechanisms: prosecuting human rights violations in domestic, foreign, international, and hybrid courts. We address two main research questions: 1) do human rights prosecutions deter future violations of human rights in transitional countries, and if so, 2) what are the mechanisms through which prosecutions lead to improvements in human rights? Because human rights trials are relatively recent phenomena, we still know little about their effects (Thoms et al., 2008:31). Although there is a large and important quantitative literature on the causes of repression, it has not addressed human rights trials. ${ }^{4}$ We draw on our new dataset on human rights prosecutions to provide the first full quantitative analysis on the impact of such prosecution on human rights practices. ${ }^{5}$

We also contrast the impact of prosecutions with that of truth commissions. This contrast helps us to develop and evaluate theoretical arguments about the mechanisms through which prosecution bring about change. Human rights trials are not only instances of punishment or enforcement, but also high-profile symbolic events that communicate and dramatize norms. It is

\footnotetext{
${ }^{4}$ Poe and Tate (1994), Poe, et. al (1999), Zanger (2000), Davenport and Armstrong II (2004), Anderson, et. al (2002), Apodaca (2001), Bueno de Mesquita et. al (2005), Richards, et. al (2001), and Hafner-Burton (2005).

${ }^{5}$ A book manuscript by Leigh Payne, Tricia Olsen, and Andrew Reiter also provides a quantitative analysis of the impact of trials and of other transitional justice mechanisms: Engaging the Past to Safeguard the Future:

Transitional Justice in Comparative Perspective.
} 
thus difficult to separate these normative and performative aspects of prosecution from its material punishment and enforcement effects. Truth commissions, which are official government bodies temporarily set up to investigate past histories of human rights violations (Hayner, 2002), also communicate norms but they do not involve any material punishment. Truth commission reports rarely give names of perpetrators, and even when they do, such naming does not lead to a material sanction. If human rights change occurs only by imposing material costs on specific individuals, we would not expect truth commissions to lead to any change. By comparing the impact of prosecution with that of truth commissions, we are able to gain an understanding of whether human rights change occurs only through enforcement involving material costs, or through some combination of material and social pressures.

Many scholars and practitioners argue that human rights trials are both legally and ethically desirable and practically useful in deterring future violations (Méndez, 1997, RohtArriaza, 1995). Mendeloff (2004:358), however, finds many claims about the positive effects of trials but relatively little solid evidence to support those claims. Others believe that prosecution will not deter future violations and that in some circumstance they will lead to an increase in repression (Snyder and Vinjamuri, 2003). In the 1980s and 1990s, scholars of democratization also generally concluded that trials for past abuses would undermine new democracies, and not have a deterrent effect (Huntington, 1991). We consider a variety of these different hypotheses from these literatures as well as from the more specialized literature on transitional justice.

Consistent with the deterrence hypothesis, we find that transitional countries with human rights prosecutions are less repressive than countries without prosecutions. Our study also shows that countries with more cumulative prosecutions are less repressive than countries with fewer prosecutions. In addition, countries with more neighbors with prosecutions are less repressive, 
which may suggest that individuals learn from the experiences in other countries to create a deterrence impact across borders. We also find that truth commissions are associated with improvements in human rights practices. Thus, we argue that both normative pressures and material punishment are at work in deterrence, and the combination of the two, as in the case of prosecution combined with truth commissions, is more effective than either pure punishment or pure normative pressure.

In the first three sections, we give a brief background on the emergence of human rights trials, review and discuss the various arguments in the transitional justice, compliance, and deterrence literatures that link human rights trials with human rights violations, and present the hypotheses to be tested. In the fourth section, we explain our dependent and independent variables and discuss our sample, which is defined as transitional states. In the next section, the statistical evidence relating trials to human rights protection is examined. Various models were used to check the robustness of the relationship, especially given the concerns about endogeneity. We conclude with a summary and suggestions for the future research.

\section{Compliance, Deterrence, Trials and Truth Commissions}

The area of human rights has experienced a dramatic increase in legalization in the post WWII period. ${ }^{6}$ In 1945 , the human rights issue area was not highly legalized at the international level. By 2000, many detailed treaties involving diverse human rights had been widely ratified and had entered into effect, but these treaties had weak enforcement mechanisms. Human rights were a highly legalized issue area but there were few tools or sanctions to enforce the law. Where accountability existed, it tended to be reputational accountability depending upon moral

\footnotetext{
${ }^{6}$ By legalization, we follow Abbott, et. al (2000) in referring to a particular form of institutionalization characterized by obligation, precision, and delegation.
} 
stigmatization of state violators. ${ }^{7}$ In the few cases where stronger enforcement mechanisms existed, especially the regional human rights courts in Europe and the Americas, the focus was on state legal accountability. That is, regional human rights courts, like the European Court of Human Rights, find that states (not individuals) are in violation of their obligations and require them to provide some kind of remedy, usually in the way of changed policy.

The international human rights regime is still mainly characterized by state accountability with weak enforcement. But for a small set of core human rights and war crimes, states and international institutions are increasingly using individual criminal accountability. ${ }^{8}$ Specific state officials are prosecuted and if found guilty, they go to prison. This change has emerged gradually over the last twenty years in international and domestic judicial processes. It reflects not only an increase in the legalization of international human rights, but a specific form of legalization one focused on individual accountability. This trend has been described by Lutz and Sikkink (2001) as "the justice cascade," and by Sriram (2003) as "a revolution in accountability." This new form of legalization is not for the whole range of human rights, but for a core set of human right violations (torture, summary execution, disappearances and political imprisonment), genocide, war crimes and crimes against humanity. ${ }^{9}$

The new focus on individual criminal accountability is reflected in the Statute of the International Criminal Court (ICC), in the ad hoc tribunals for the former Yugoslavia (ICTY)

\footnotetext{
${ }^{7}$ We use Grant and Keohane's (2005) definition of accountability that implies that "some actors have the right to hold other actors to a set of standards, then judge whether they have fulfilled their responsibility and to impose sanctions if they determine these responsibilities have not been met." Reputational accountability is one of the seven forms of accountability they discuss.

${ }^{8}$ The legal literature uses the term "individual criminal responsibility" for core international crimes subject to the jurisdiction of the ICC. See Damgaard (2008). Ratner and Abrams (2001) also use the term "individual accountability for human rights abuses" to refer to the broader phenomena of holding individual state officials responsibility for human rights violations. We use the term individual criminal accountability both to signal that we are interested in the broader phenomena and to clarify that our data base does not include civil claims.

${ }^{9}$ Thus, the legalization discussed here enforces many of the non-derogable rights in the International Covenant on Civil and Political Rights (ICCPR), the Genocide Convention, the Convention against Torture (CAT), those parts of the Geneva Conventions prohibiting war crimes, and the Rome Statute of the ICC.
} 
and Rwanda (ICTR) and in the foreign universal jurisdiction cases like that against former Chilean President Augusto Pinochet (Bassiouni, 1996, Macedo, 2004, Roht-Arriaza, 2005). But the change has not been limited to these high-profile international tribunals and foreign cases. It is a more profound shift that also includes changes in domestic institutions. The great bulk of enforcement of core human rights norms now occurs in domestic courts using a combination of national criminal law, international criminal law, and international human rights law. Even when they primarily use domestic criminal law, human rights prosecutions differ from ordinary criminal trials because they involve state officials, who historically had immunity from prosecution (Ratner and Abrams, 2001).

Our research focuses on prosecuting human rights violations in domestic, foreign, international, and hybrid courts. By prosecuting human rights violations, we refer to processes including indictments, arrests, extraditions, detention, as well as trials for violations of core human rights by state officials. Prosecuting human rights violations can be seen as a form of enforcement because it imposes costs and sanctions on state officials and carries the possibility of punishment. Even when trials do not result in convictions and incarceration, they can impose substantial costs on individuals, including the financial costs of litigation, the lost income during preventive detention, and importantly for elites, a loss of prestige and legitimacy.

We include prosecutions that impose costs on the accused even when they do not result in convictions because we believe that such costs are relevant to explain deterrence. So, for example, the prosecutions of Augusto Pinochet in the United Kingdom and in Chile did not result in a conviction. Although Pinochet was never convicted of human right crimes, most would agree that his detention and trial was very costly to him. Likewise, Slobodan Milosevic died before he faced conviction by the ICTY, and yet his indictment, extradition to Hague, and 
detention and trial there was all very costly to him. Many believe such arrests and trials send "shock waves into the homes of other leaders," and thus may deter future human rights violations, a hypothesis we test here (Goldstone, 2000:136).

\section{Does Prosecuting Human Rights Deter Future Violations?}

International relations and legal scholars have long been concerned with the conditions under which governments comply with their commitments (Raustiala and Slaughter, 2002). What leads states to bring their behavior into greater conformity with international law? Many legal scholars believe that norms themselves induce a sense of obligation in states to comply (Chayes and Chayes, 1993, Koh, 1997). A more common hypothesis in the international relations compliance literature is a rationalist one that argues that an increase in enforcement should lead to an increase in cooperation (Downs et al., 1996). Because prosecuting human rights violations can be conceptualized as a form of enforcement that imposes new costs on state officials, an exploration of whether such prosecutions lead states and government officials to comply more with human rights law can help illuminate these larger debates over compliance and enforcement.

The debate over human rights trials is also related to an important literature on deterrence in domestic legal systems (Andenaes, 1974, Blumstein et al., 1978, Matsueda et al., 2006, McCarthy, 2002, Nagin, 1998). This literature is similar to the compliance literature in that it is concerned with the degree to which sanctions and enforcement influence compliance with laws, but the deterrence literature has focused almost exclusively on how domestic prosecution and punishment inhibit individual criminal activity in the country where the prosecution occurs. It is relevant to our study because these also involve imposing domestic sanctions on individuals with 
the aim of preventing future violations. In this literature, deterrence is defined as "the inhibiting effect of sanctions on the criminal activity of people other than the sanctioned offender (Blumstein, et al., 1978)." After the ICTY indicted Milosevic for crimes in Bosnia, he went on to commit further violations in Kosovo. Some said this was a failure of deterrence. But as the definition above makes clear deterrence theory does not anticipate that sanctioned offenders who have already committed human rights violations will be deterred from committing further violations. Rather, it is concerned with how sanctions affect future behavior of other actors. Individuals who have already committed crimes can be "incapacitated" or "preempted" from committing future crimes by incarceration, but they are not the subjects of deterrence (Blumstein, et al., 1978).

Reviews of the deterrence literature from domestic legal systems now conclude that there is much firmer evidence for a substantial deterrent effect than there was two decades ago (Nagin, 1998). Of particular relevance to our study is the finding that beliefs about the likelihood or probability of arrest and punishment have more deterrent effects than increases in the severity of punishment (Becker, 1968, Bueno de Mesquita, 1995, McCarthy, 2002, Nagin, 1998). In other words, research on domestic crimes rates has not shown that more severe punishment, such as the death penalty, deters crime, but it does indicate that increases in the likelihood of sanctions is associated with deterrence.

What has changed dramatically in the realm of international human rights is exactly this likelihood of individual sanctions of state officials. Prior to the 1970 s, there was an almost zero likelihood that heads of state and state officials would be held accountable for past violations. ${ }^{10}$

\footnotetext{
${ }^{10}$ The Nuremberg and Tokyo trials, and other WWII successor trials were the important exceptions to this rule, but they were also exceptions that proved the rule. Only leaders who ordered such crimes and then were unconditionally defeated could indeed be held individually responsible for their crimes by the victors or by domestic or foreign courts.
} 
In principle, citizens could have used domestic criminal law to hold their past leaders legally accountable, but doctrines granting immunity to state officials from prosecution and the continuing power of these leaders prevented such accountability. Our data indicate that in the 1980s and 1990s the observable likelihood of sanctions for past violations has increased from almost zero to some positive number in many countries. Indeed the international realm may provide some kind of natural experiment for deterrence theory, since a major change in this key variable, the likelihood of sanction, has occurred in a relatively short period of time.

A contrary argument comes from the literature that suggests that more enforcement of human rights norms and law can be counterproductive and actually lead to more violations of the law. Jack Goldsmith and Stephen D. Krasner (2003: 51) contend that "a universal jurisdiction prosecution may cause more harm than the original crime it purports to address." They argue that states that reject amnesty and insist on criminal prosecution can prolong conflict, resulting in more deaths. Jack Snyder and Leslie Vinjamuri (2003) also argue that human rights trials themselves can increase the likelihood of future atrocities, exacerbate conflict, and undermine efforts to create democracy. These arguments suggest that more enforcement or the wrong kind of enforcement can lead to less compliance with international and domestic law. In particular, they suggest that during civil wars, insurgents will not sign peace agreements if they fear they will be held accountable for past abuses and the prolonged war can seriously exacerbate human rights violations.

Until now, this debate has been carried on through the use of qualitative comparative case studies and counterfactual arguments. This has been necessary because there was no data on human rights trials. Our new data, however, allows us to test quantitatively for the first time two hypotheses about human rights prosecutions and deterrence. 
Hypothesis 1: Countries that have held domestic human rights prosecutions or whose officials have been the object of foreign or international prosecutions will see greater improvements in human rights practices than those countries that have not held or been the object of human rights prosecutions.

Hypothesis 2: Under situations of civil conflict and war, human rights prosecutions will exacerbate human rights violations.

\section{Through Which Mechanisms Do Human Rights Prosecutions affect Repression?}

Once we establish if human rights prosecutions are associated with improvements in human rights, we need to ask about the mechanisms through which these improvements occur. One key literature on mechanisms is the rational choice literature on the causes of repression. This literature argues that state officials choose repression because the benefits gained from repression exceed the costs (Poe, 2004). From this point of view, the expected benefits of repression may include the political gains for repressing political opponents, and the financial gains of expropriating their wealth and property. Prosecutions lead to sanctions of various sorts (arrest, incarceration, loss of income or prestige) that may increase the perceived costs of repression. For this approach, the main mechanism through which prosecutions lead to improvements in human rights practices is by increasing the costs of repression for state officials at the same time as the benefits of repression remain constant. Although this literature does not exclude social costs, the focus has been on the material costs and benefits.

The alternative to the rational choice models are norm models that say that sometimes deterrence or compliance occurs for normative or managerial reasons even in the absence of 
strong enforcement (Chayes and Chayes, 1993). Since issues of state and individual reputation, esteem, and legitimacy are at stake in human rights debates, the processes of the mobilization of shame through advocacy networks and international organizations could lead to behavioral change without stronger enforcement (Risse et al., 1999). In this approach, trials and truth commission are also a part of a process of socialization through which the norms of domestic and international society are communicated and reinforced, not only to state officials, but also to broader publics. Deterrence research suggests that deterrence is more effective for individuals who have a higher stakes in society or in conventionality (McCarthy, 2002, Nagin, 1998) which would include current and future state officials. Norm models stress that state officials also care about the social costs imposed by trials, and are attentive to the general norms of society and the role of institutions, including judicial institutions in communicating those norms. But we should be clear that the norms literature does not say that stronger enforcement is counterproductive for compliance, just that strong enforcement may not be necessary in all circumstances and that behavioral change is possible in the absence of enforcement mechanisms.

Many legal scholars and political science norms theorists who write on human rights believe that human rights change is usually the result of both normative and coercive factors, such as aid cut-offs or other sanctions (Akhaven, 2001:13, Cardenas, 2007, Risse, et al., 1999, Weissbrodt and Bartolomei, 1991). Thus, they would tend to agree that the greater enforcement of human rights norms through prosecutions will complement and enhance the processes of "naming and shaming" that have long been a staple of the human rights movement. Nevertheless, it may be useful for analytical purposes to try to separate out the "punishment costs" of prosecutions that are mainly of concern to the rational choice literature, and the socialization processes that have been stressed in the norms literature. Such an effort would help us 
understand better the mechanisms through which prosecutions affect human rights practices. The dilemma with prosecutions is that they are simultaneously highly symbolic normative events and a key form of material sanctions. It is difficult to isolate the material costs of prosecutions from their social effects as expressions of social disapproval. Informal social sanctions may follow from the formal sanctions of trials, and can have important effects in political arenas where reputation is essential.

By comparing the impact of truth commissions and human rights prosecutions, however, we may be able to separate out a more purely normative mechanism from one that imposes both material and social costs. Because truth commissions do not result in any material punishment of individuals, if only material costs matter, truth commissions are unlikely to have any independent effect on human rights practices. If, however, both social and material costs are important, we would expect to see that truth commissions have an impact on human rights practices.

Finally, we test an additional hypothesis extrapolated from the deterrence literature. Studies show that countries can learn from the policies of other countries (Haas, 1992, Weyland, 2005). Given the high-profile nature on many human rights prosecutions, human rights prosecutions might have a deterrence impact beyond the confines of the single country in which they are held, or to which they refer. For example, we might anticipate that prosecutions like that of Pinochet would have an impact beyond Chile. We will refer to these possible phenomena as “deterrence across borders" and will examine it by exploring the impact that prosecutions have on human rights practices in neighboring countries. While we cannot be certain of the mechanisms through which deterrence across borders works, we posit that it involves both a fear of punishment and a normative socialization process. If a neighboring country holds human 
rights trials, it does not objectively increase the possibility of material punishment in the home country but it may increase the fear of anticipated costs on perpetrators across the border. But it also communicates regional or international norms and expectations about behavior. This discussion leads to the following two additional hypotheses. Support for these hypotheses in turn suggests that deterrence involves normative mechanisms as well as the material costs of punishment.

Hypothesis 3: The use of a truth commissions will also be associated with improvements in human rights practices.

Hypothesis 4: Human rights prosecutions will have a positive impact on the improvement of human rights protection in neighboring countries.

\section{Research Design}

To test these hypotheses, we use our new data on domestic and international human rights prosecutions in transitional countries between 1980 and 2004. We test our hypotheses with transitional countries for two reasons. First, we exclude fully authoritarian countries because generally they do not hold free and fair trials, nor do they have an independent judiciary. Thus we could not be confident that genuine trials of state officials for human rights violations can be held there. In the absence of an independent judiciary, for example, what might appear on the surface to be a human rights trial might instead be a show trial or a political trial through which the authoritarian leader punishes his opponents. Second, the theoretical literature directs our attention to the possible effects of prosecutions in transitional societies. The entire transitional justice literature is premised on the notion that transitional societies are in processes of instability 
and flux in which choices made about accountability could have an enduring impact (Kritz, 1995, McAdams, 1997, Minow, 1998). These arguments, however, have not received adequate testing. Important new work by Simmons (2009:14) also demonstrates that human rights law has had more impact in a subset of transitional societies, "where institutions are more fluid," than in fully authoritarian or fully democratic countries. Simmons, however, does not examine the impact of human rights prosecutions. There is no corresponding theoretical literature that posits that human rights prosecutions will have an important impact on the already high level of human rights protections in democratic societies. In stable democracies, Simmons shows, human rights law is often "redundant" and has less of an impact.

Our dataset uses the country year as its unit of analysis. We used a variety of time-series cross-sectional models, including models that allow us to address a reciprocal relationship. We include all states which have experienced a transition since 1974. Countries with three types of transition were considered: democratic transition, transition from civil war, and transition by state creation. We determined our sample using the Polity IV dataset and found 100 transitional countries. $^{11}$ (Appendix 1)

\section{The Dependent Variable - Repression}

We explore the impact that human rights prosecutions and truth commissions have on a core set of human rights violations - torture, summary execution, disappearances and political

\footnotetext{
${ }^{11}$ The regime transition variable (Regtrans), which was derived from the yearly changing values of the Polity score, was used. We began with all 192 countries and excluded 32 countries with population less than 500,000. We went through three steps to determine our sample. First, the Regtrans is a 6-point scale regime change variable, which ' +3 ' means a major democratic transition, ' +2 ', a minor democratic transition, and so forth until ' -2 ', an adverse regime transition. States with ' +3 ' and ' +2 ' scores between 1974 and 2004 were examined and we found 68 countries with democratic transition. Second, state failure is coded as ' -77 ' and states were categorized to have experienced a transition from civil war if that country has exited from the state failure period by a regime change (' 0 ' or ' ' 1 '), interruption ('-66'), or transition ('-88') and found 16 countries. Third, state creation was recorded as state creation ('99') or state transformation ('97') and we found 28 countries. We found 12 counties with multiple types of transition and all transitions in a chronological order were included.
} 
imprisonment - which we refer to as repression, following established practice in the quantitative literature (Poe, et al., 1999). Human rights prosecutions mainly address these violations, so we should look for impact on a dependent variable that is a measure of these physical integrity rights. We operationalize it using the physical integrity rights index from the Cingranelli-Richards (2004) human rights database (CIRI) and we reversed the original index into a 9-point scale where " 8 " indicates the highest level of repression and " 0 " indicates an absence of repression. The physical integrity rights index and human rights prosecution data are coded from different sections of the U.S. Department of State Country Reports on Human Rights Practices, and we could not find any evidence that prosecution activities were used in coding any of four elements of the physical integrity rights index (Cingranelli and Richards, 2004). In addition, we checked our findings using an alternative measure - the political terror scale, which was coded from both the Amnesty International reports and State Department reports (Gibney, 2004) and could not find differences in our results.
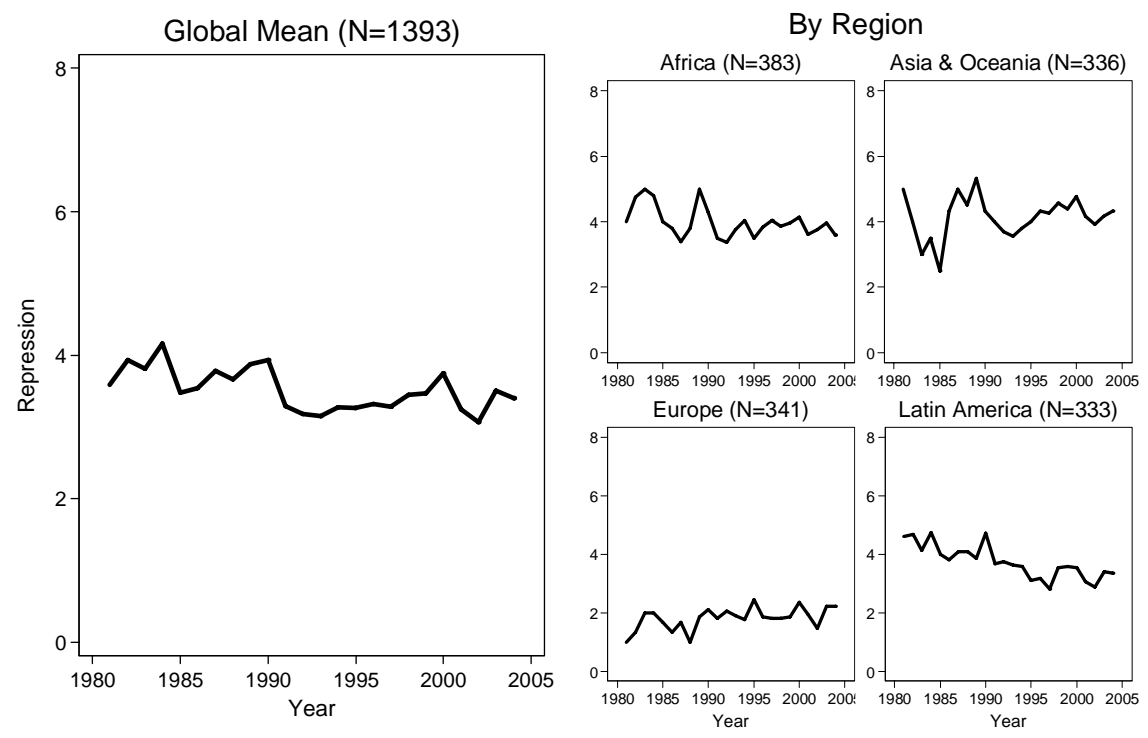

Figure 1. Change in the Average Score of Repression over Time 
Figure 1 summarizes the change in the mean score of repression over time. The graph on the left panel represents the mean score of the all transitional countries. The average level of repression is fairly constant but we can see a slight drop over time. Moreover, there are visible discrepancies when we examine the average level of repression by region. While European countries show quite stable low levels of repression, we can a see substantial decrease in the level of repression in Latin American countries.

\section{The Independent Variable - Human Rights Prosecutions}

Both domestic and international human rights prosecutions were considered in our analysis. Domestic prosecutions are those conducted in a single country for human rights abuses committed in that country. International prosecutions include prosecutions for individual criminal accountability in international tribunals like the ICTY and ICTR, in hybrid tribunals like in Sierra Leone. They also include foreign prosecutions like the Pinochet case in the United Kingdom where prosecution activities are conducted in a single country for human rights abuses committed in another country. When combined, domestic prosecutions make up the great bulk of total prosecutions and only nine percent of the total prosecution years involve solely international prosecutions. Thus, we examined the combined effect of domestic and international prosecutions in our analysis. While information is readily available on the relatively small number of international trials, the data on domestic and foreign trials is dispersed and difficult to quantify. To address this problem, we created a new database of human rights prosecutions by coding from the State Department reports, which are generally considered to be a reliable source of information on states' human rights practices (Poe et al., 2001). Because the State Department only systemically reports on states' domestic prosecution activity, in the case of foreign and international prosecutions we have supplemented the State Department reports with information 
gathered from human rights nongovernmental organizations (NGOs) and intergovernmental institutions. $^{12}$

To be included in the dataset the prosecution activity discussed in the report must inflict costs on a government agent accused of having individual criminal responsibility for human rights violations. Some of our trials involve former heads of state and high level officials, but trials of lower level officials including police officers and prison guards are also included. Prosecutions can be initiated either by governments themselves or by individuals or groups. In common law countries, only governments initiate criminal prosecutions, but in some civil law systems, victims and groups representing victims acting as "private prosecutors" may initiate criminal proceedings either directly or indirectly (Brienen and Hoegen, 2000, Office of Justice Programs, 2009).

When our data sources mentioned prosecutions that met the criteria, a country is coded "1" for having human rights prosecutions in a given year (a country prosecution year). If there was no mention of a trial, a country was coded " 0 " for that year. This coding decision gives us a level of precision we believe is appropriate to the available data. The State Department report and our other sources of data are simply not complete enough to permit a precise count of the actual numbers of human rights trials or convictions, nor to compare the nature or quality of prosecutions between different countries. This decision has the effect of underestimating the number of prosecutions because no matter how many trials are occurring, a country is still only coded "1" for that year. Nevertheless, a country that has an active program of human rights prosecutions accumulates over time a score that we call "cumulative prosecution years" that

\footnotetext{
${ }^{12}$ Information was collected from documents and reports from the U.N. Security Council, ICC, ICTY, and ICTR. Additional information was found in the following NGOs: Human Rights Watch, International Center for Transitional Justice, Coalition for International Justice, Prevent Genocide International, REDRESS, Universal Jurisdiction Information Network, Global Policy.org, and Track Impunity Always.
} 
allows us to distinguish those countries making significant efforts at accountability from countries that have held no or few trials. More precise information on the actual number of trials occurring at any one time is only available for a handful of countries. ${ }^{13}$

Two measures of human rights prosecutions were used. First, a dichotomous variable was created to track whether a country had a prosecution at any point after transition - human rights prosecution (HRP). Second, a continuous measure of cumulative prosecution years (CHRP), which provides more extensive within-state and between-state variation, was also used. The CHRP variable captures the persistence and frequency of trials in the country. Our cases include 48 countries with a human rights prosecution, including 33 countries with two or more cumulative prosecution years. (Appendix 2)

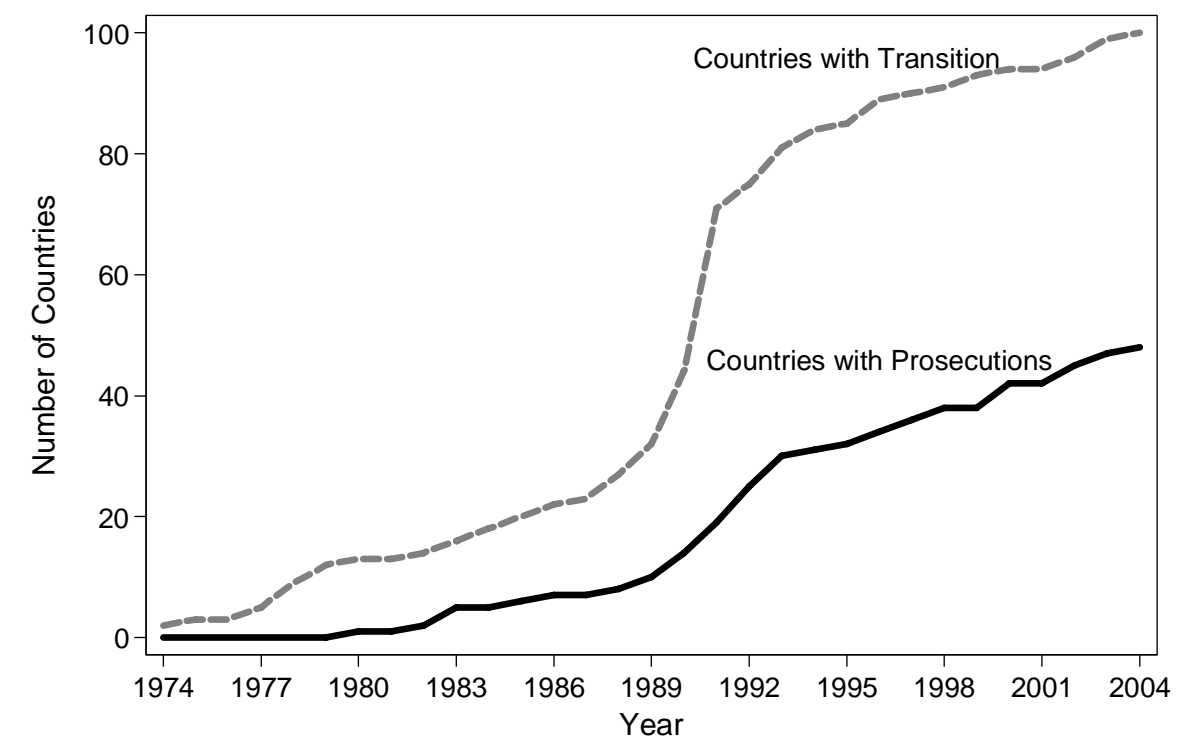

Figure 2. The Number of States with Transition and Human Rights Prosecutions

\footnotetext{
${ }^{13}$ In Argentina in 2008, over 212 human rights lawsuits are currently in process, and 330 individuals that have been accused are being held in preventive imprisonment (Centro de Estudios Legales y Sociales). Yet we would code Argentina as " 1 " for 2008, and its number of cumulative prosecution years is 20 for the entire period.
} 
Figure 2 supports our argument that the likelihood of sanctions increased over the last 20 years.

The dashed line shows the number of countries experiencing transition between 1980 and 2004 .

We see a steady increase in the number before 1989 and a sudden rise between 1989 and 1992

reflecting the collapse of the Soviet Union and the Eastern European regimes. The lower solid

line shows the steady increase of states with human rights prosecutions after 1980. During these

years, cumulative prosecution years also increased globally and regionally. Latin America is

certainly leading the trend, but prosecution years in Africa and Europe also increased.

\section{Models}

The basic structure of the data is an unbalanced time-series cross-sectional data. Three models were used. First, in line with most studies of repression, we used pooled ordinary least squares (OLS) regression with panel corrected standard errors (PCSE) and a lagged dependent variable (Beck and Katz, 1995, Poe, et al., 1999). ${ }^{14}$ The basic PCSE model is:

$$
Y_{i, t}=\beta_{0}+\beta_{1} Y_{i, t-1}+\beta_{2} X_{i, t}+\gamma Z_{i, t}+e_{i, t},
$$

where $Y_{i, t}$ represents our measure of repression, $Y_{i, t-1}$ is a one year lag of the dependent variable, $X_{i, t}$ is the respective measure of prosecution - either HRP or CHRP, $Z_{i, t}$ is a vector of control variables, and $e_{i, t}$ is a error term. ${ }^{15}$

A set of control variables is included to isolate the net effect of human rights prosecutions from all other factors that might affect the level of repression. Guided by previous studies, eight

\footnotetext{
${ }^{14}$ Due to the ordinal character of the dependent variable, some researchers (Hafner-Burton, 2005, Walker, 2006) use ordered probit or logit models. We estimated ordered models and the results are the same. However, we did not use ordered model for two reasons. First, although we tried ordered models with a lagged dependent variable and a Markov transition, the problem of temporal autocorrelation cannot be easily resolved in ordered models. Second, techniques are not readily available to estimate simultaneous equation models. Since controlling for endogeneity is a larger concern for us, we did not use ordered models.

${ }^{15}$ Some (Achen, 2000, Keele and Kelly, 2006) show concerns regarding using a lagged dependent variable in timeseries cross-sectional data. Thus, we additionally estimated our models using Prais-Winsten regression with panel corrected standard errors assuming a first-order autoregressive error process and the results are the same.
} 
control variables - democracy, international wars, civil wars, treaty ratification, economic standing, economic growth, population size, and population growth - were included. We anticipate that factors that were proven to be important in the previous studies will continue to be important. Additionally, we included four regional dummy variables and a linear time variable to control for spatial and temporal discrepancies. ${ }^{16}$ (Appendix 3)

Second, country-specific fixed-effects regression models were used. Fixed effects regression is an effective way to examine how changes in human rights prosecutions affect repression in a given state. The basic fixed effects model is:

$$
Y_{i, t}=\beta_{0}+\beta_{1} Y_{i, t-1}+\beta_{2} X_{i, t}+\gamma Z_{i, t}+u_{i}+e_{i, t}
$$

where $u_{i}$ is the country-specific fixed effects and other notations are the same as the PCSE model. ${ }^{17}$

The final model deals with the possibility of reverse causation in our previous equations. It is possible that repression itself could affect the likelihood and persistence of human rights prosecutions. Many think that endogeneity is possible because the main function of prosecutions is to address past human rights violations. Thus the current level of repression possibly determines whether a country will have human rights prosecution, and for how many years it will continue to pursue prosecutions. If this effect were true, then the resulting endogeneity of our prosecutions variable will bias our coefficient estimates. Thus, we employed a two-stage estimation of simultaneous equations. The basic model comprises two equations:

$$
\begin{aligned}
& Y_{i, t}=\beta_{0}+\beta_{1} Y_{i, t-1}+\beta_{2} X_{i, t}+\gamma Z_{i, t}+e_{i, t} \\
& X_{i, t}=f\left(K_{i, t}, v_{i, t}\right)
\end{aligned}
$$

\footnotetext{
${ }^{16}$ The regional dummy variables were created using the U.N. regional division of the world - Africa, Asia, Oceania, Europe, and Latin America (as an omitted base category).

${ }^{17}$ Since the use of fixed effects with a lagged dependent variable might be problematic (Nickell, 1981), we ran all fixed effects regressions without a lagged dependent variable and found the results unchanging.
} 
, where $K_{i, t}$ in the second equation is a vector of variables that we expect to affect either the use of prosecutions or the number of years a state use prosecutions, including the level of repression, $v_{i, t}$ is an error term of the second equation, and all other notations are the same as the PCSE model. Depending on the function $(f)$ - probit for the dichotomous variable (HRP) and linear regression for the continuous variable (CHRP) - two-stage probit least squares (2SPLS) (Alvarez and Glasgow, 1999) or generalized two-stage least squares (G2SLS) was estimated.

In the two-stage models, we first estimate the reduced form equation by regressing $X_{i, t}$ using all of the exogenous variables in the $\operatorname{system}\left(Y_{i, t-1}, Z_{i, t}\right.$, and $\left.K_{i, t}\right)$. Then, from the reduced form estimates, we compute the predictors for the prosecution variable and substitute these values for the endogenous regressors in the second-stage structural equation. The results of this second stage analysis will produce consistent estimates of the model parameters but the standard errors should be corrected because they are based on the predicted values of the endogenous explanatory factor. Based on Kim's (2008) previous study on the adoption of human rights prosecutions in transitional countries, the second equation was estimated using the past level of repression, regional precedents, truth commission, democracy, domestic human rights advocacy, human rights treaty ratification, legal tradition, economic standing, economic growth, and types of transition.

\section{Findings}




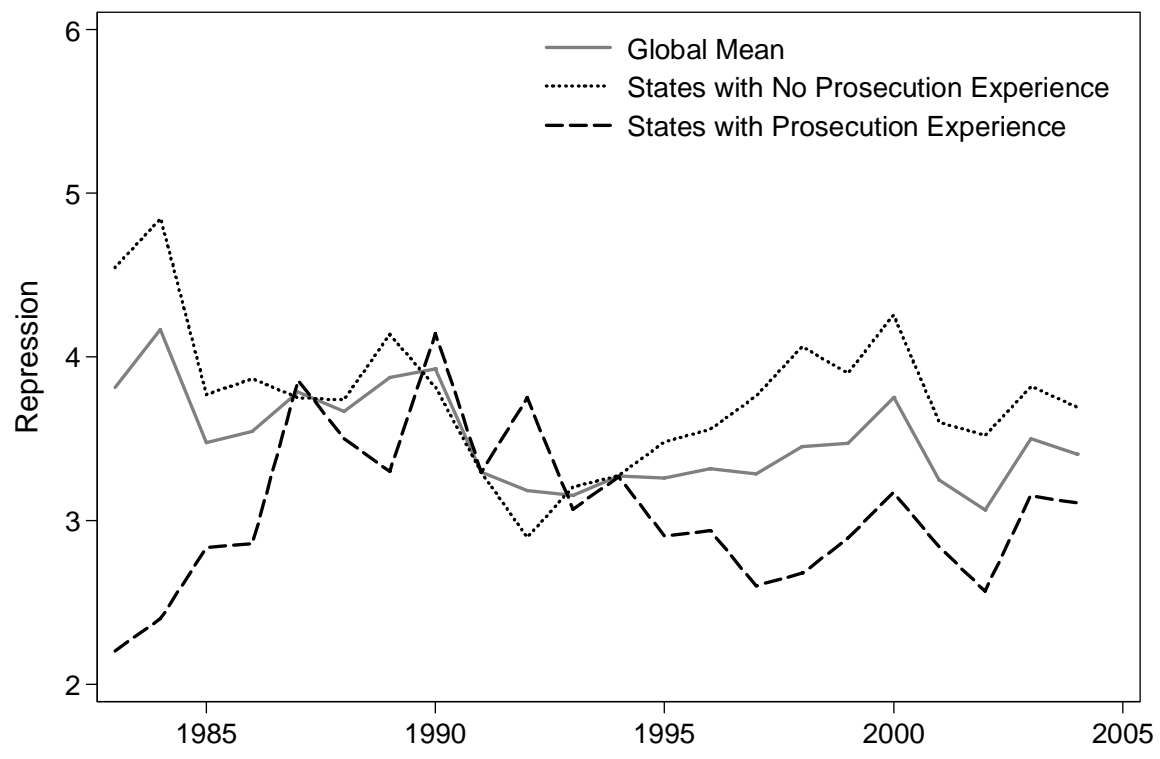

Figure 3. Changes in Mean Score of Repression by Prosecution Experience

Figure 3 shows the changes in the average repression score for countries with different prosecution experiences. A gray solid line indicates the changes in the yearly mean of the repression score and we compared the yearly mean score of countries with human rights prosecutions (dash) to those without prosecutions (dot). The distinction between the two lines is clear before 1987 and becomes clear and stable after 1994. The average repression score of countries without prosecutions are constantly above the average while the mean repression score of countries with prosecutions are below the average.

\section{(Table 1)}

Table 1 reports the results of estimating the effect of prosecutions using PCSE models. Model 1 is an extension of Poe et. al's (1999) model to our sample. Although we examined transitional states for a longer period, our findings are consistent with previous studies. 
Democracy, civil war, economic standing, population size, and past level of repression turn out to be relevant factors affecting the level of repression. Model $2 \mathrm{a}$ and $2 \mathrm{~b}$ are our baseline models where the HRP or CHRP variables are included along with the truth commission variable. The result reveals that human rights prosecutions have a strong and statistically significant impact on decreasing the level of repression. ${ }^{18}$ When controlled for all other relevant factors, the level of repression in countries with prosecutions is significantly lower than that of countries without prosecutions. Moreover, not only prosecution experience but also the persistence and frequency of prosecutions matter. In Model $2 \mathrm{~b}$, the level of repression decreases as the number of years with human rights prosecutions increases. If a country were to move from the minimum (0) to the maximum possible number of prosecution years (20), this would bring about a 0.34 point decrease in the repression scale.

The coefficients of the prosecution variables represent the short-term effect. Due to the inclusion of the lagged dependent variable, the total effects are also dynamically distributed across time. The long-term effects are those that accrue over time through the operation of the lagged dependent variable. These long-term effects are permanent effects that become realized after several years. ${ }^{19}$

\footnotetext{
${ }^{18}$ There are bivariate relations between prosecutions and repression. The regression estimates of prosecution variables for Model 2a is $\beta=-0.673$ ( $\mathrm{SE}=0.119, p<0.001$ ) and for Model 2b, $\beta=-0.405(\mathrm{SE}=0.076, p<0.001$ ).

${ }^{19}$ The long-term effects are calculated by $\beta /(1-\alpha)$, where $\beta$ is the coefficient on the prosecution variables and $\alpha$ is the coefficient on the lagged dependent variable.
} 


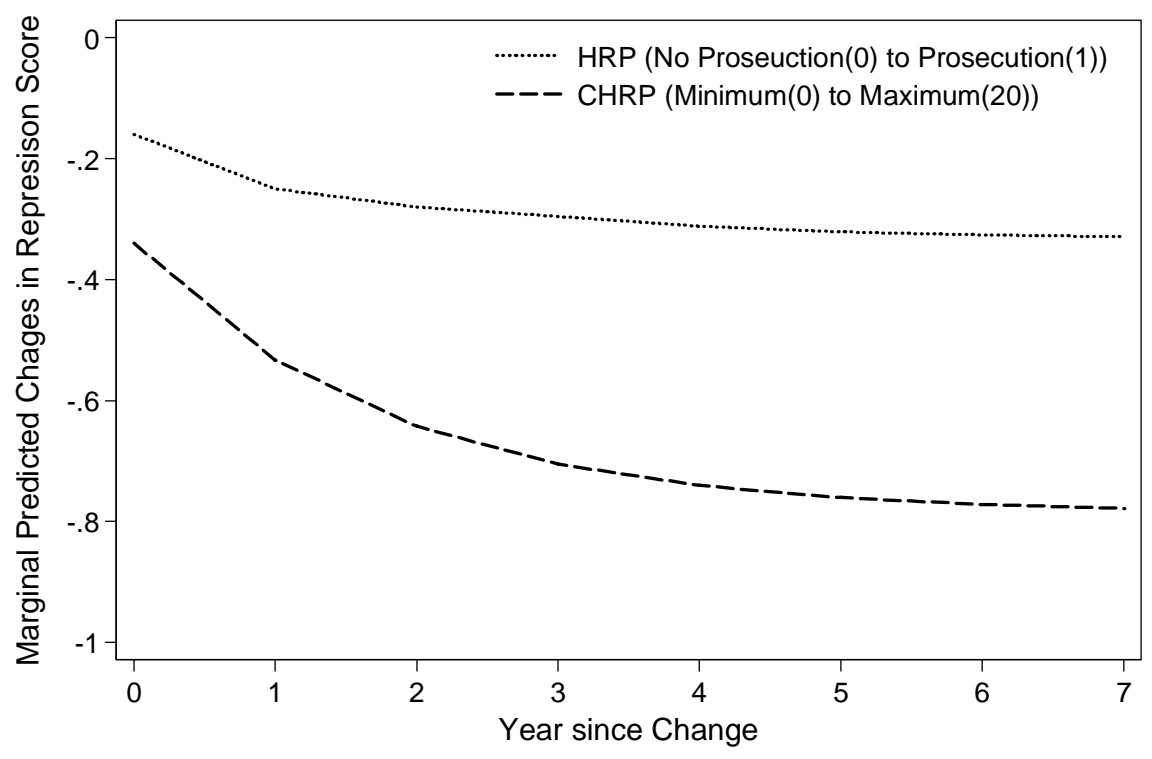

Figure 4. Long-term Effect of Human Rights Prosecutions over Time

Figure 4 presents the estimated dynamic effects of human rights prosecutions if the average country were to move from no prosecution to at least one prosecution (dot) or from no prosecution to the maximum possible prosecution years (dash). Note that by five years most of the impact is predicted and from seven year onwards there is negligible change. If a country starts to have a prosecution, the repression score would decrease by 0.16 points in the immediate year and about 0.32 points after five years. The movement from zero prosecution years to the maximum number of prosecution years (20) starts with a 0.34 point decrease, and stabilizes at about a 0.78 point decrease. This is not a small change if we compare the effects of prosecutions to the effects of democracy on repression. From Table 1, the maximum possible effect of the levels of democracy on the repression scale is a decrease of 1.12 points. That is, if an average country were to change from the worst authoritarian regime to the best democratic regime, the difference in its score would be 1.12 points. Thus, a 0.78 point decrease induced by the changes in human rights prosecutions is a significant change. 
The truth commission variable was included both as a control variable to estimate the net effect of prosecutions and as an independent variable. Truth commission experience also contributes to improved human rights protection. A truth commission brings about a 0.19 point decrease in the repression score in the short-term and a 0.43 point decrease in the long-term. If a country were to have both a human rights prosecution and a truth commission that would bring about a 0.35 point decrease in the short-term and a 0.8 points decrease in a long-term.

In sum, we found that countries with human rights prosecutions have better human rights practices than countries without prosecutions. In addition, countries that have experienced more prosecutions over time (and thus a greater likelihood of sanctions for past human rights abuses) have better human rights practices than countries without or had fewer prosecutions. Contrary to the arguments made by some scholars, human rights prosecutions have not tended to exacerbate human rights practices. A truth commission experience also has a positive impact on human rights. This suggests that the mechanisms through which transitional justice measures influence human rights do not only involve a calculation of the possibility of punishment, but also respond to processes that provide information and communicate norms.

(Table 2 and 3)

We also performed robustness checks using various model. First, Table 2 presents the results from the country-specific fixed-effects models (Green et al., 2001). In the fixed-effects regressions, the important control variables - democracy, civil war, international war, and past level of repression - maintain their direction and significance. ${ }^{20}$ Moreover, the deterrence effect

\footnotetext{
${ }^{20}$ However, some other variables either lost their significance (economic standing), changed direction of influence (population size) or gained significance (economic development).
} 
of human rights prosecutions and truth commissions is robust in all models. Table 3 presents the estimation from the two-stage models. Model 4a is a two-stage probit least squares model (2SPLS) in which one of the endogenous variables is continuous and the other variable is dichotomous. ${ }^{21}$ Model $4 \mathrm{~b}$ presents our results from generalized two-stage least squares estimation (G2SLS). Since we substituted the predictors from the reduced form equation for our original prosecution variables, it is difficult to understand the magnitude of our imputed prosecution variables in the structural equation. Nevertheless, the prosecution variables still have statistical significance and the directions of influence are the same.

(Table 4)

The models in Table 4 test hypothesis \#2 - the impact of prosecutions under civil war situations - by including two interaction terms. There are two pathways through which civil war situations could affect the impact of prosecutions on repression. The most important one is that, in situations of civil wars, the demand for human rights prosecution can delay a peace agreement. Because civil war in particular is associated with repression, anything that prolongs war could have the effect of exacerbating human rights abuses. A second possible logic is that in countries that have experienced recent civil wars, the demand for prosecutions can lead to another civil war. Once again, because civil wars are more likely to cause higher levels of repression, if the demand for trials undermines peace, it could lead to an increase in human rights violations. In our sample, 53 countries - 265 country years $(18 \%)$ - were recorded as having minor or major

${ }^{21}$ We used cdsimeq command in Stata 9.2/SE to estimate this model (Keshk, 2003). 
civil strife after transition. ${ }^{22}$ In addition, 16 countries - 124 country years (8.4\%) - have gone through transitions from civil wars. These variations allow us to effectively examine the different effects of prosecutions under situations of past or current civil war.

We included two interaction terms in our baseline models. First, we included interaction terms of the civil conflict variable and prosecution variables. This specification allows us to test whether prosecutions combined with any civil conflict situations may have a different impact. It is possible to test the first causal logic because this allows us to distinguish the different impact of prosecutions under civil wars. Second, we included interaction terms of the civil war transition variable and prosecution variables. This interaction term distinguishes the different impact of prosecutions in countries that recently have gone through transitions from civil wars to peace, that is, countries that are most vulnerable to another civil war. This specification allows us to test the second causal logic by examining whether prosecutions in such countries have a different impact.

As seen in Table 4, the independent effects of prosecutions are still significant when interaction terms are included. The more interesting aspect is the coefficient of the interaction terms, which represents the effect of prosecutions under a civil war situation. If Snyder and Vinjamuri's (2003) argument were valid, we would expect to see a positive sign in the coefficients and find statistical significance. However, we do not find this. First, prosecutions under civil wars do not have a different impact on repression than those in peace. Moreover, Model $5 \mathrm{~b}$ suggests that prosecutions during civil wars may even lead to greater improvements in

\footnotetext{
${ }^{22}$ These countries are Afghanistan, Algeria, Angola, Azerbaijan, Bangladesh, Bosnia and Herzegovina, Burkina Faso, Burundi, Cambodia, Central African Republic, Chad, Comoros, Republic of Congo, Cote d'Ivoire, Croatia, Djibouti, El Salvador, Ethiopia, Georgia, Ghana, Guatemala, Guinea-Bissau, Haiti, Indonesia, Iran, Kenya, Kyrgyz Republic, Liberia, Macedonia, Mali, Mexico, Moldova, Nepal, Niger, Nigeria, Pakistan, Panama, Paraguay, Peru, Philippines, Romania, Russia, Rwanda, Senegal, Serbia and Montenegro, Sierra Leone, Spain, Tajikistan, Thailand, Turkey, Uganda, Uzbekistan, and Yemen.
} 
human rights protections than prosecutions in peace. The impact of more frequent and persistent human rights prosecutions is proven to be more effective when a country is undergoing civil conflicts. Second, our result shows that prosecutions in countries with civil war transitions do not have a different impact on repression than those in countries with other types of transition. Our finding is consistent with Lie, et. al (2007) who recently found empirical evidence that postconflict trials lead to more durable peace.

(Table 5)

Table 5 shows the effect of prosecutions under various civil war-related scenarios. First, if a country did not have a civil war and is not currently experiencing one ( $75 \%$ of our sample), prosecutions improve human rights protection. The deterrence effect of prosecutions extends to a country that is undergoing a minor civil strife with no previous civil war experience. This provides counterevidence to the argument that prosecutions under civil war situations are less effective or counterproductive. Although civil wars certainly exacerbate repression, human rights prosecutions still appear to have a positive impact on human rights protection in those situations. Moreover, an independent effect of truth commissions also holds under civil war situations as seen in Table 4.

\section{(Table 6)}

The models in Table 6 test hypothesis \#4 - the possible deterrence effect across borders. Policy diffusion and treaty ratification studies agree that geographic proximity is the most 
important determinant of policy diffusion (Berry and Berry, 1990, Mooney, 2001, Simmons, 2000). ${ }^{23}$ Both models show that human rights prosecutions in neighboring countries around a particular country decrease repression for that country, which suggests a deterrence impact across borders. From Model 6a, we learn that a state with no prosecutions may experience a similar deterrent effect of human rights prosecutions as a state with its own prosecutions if four or more of its neighbors had prosecutions. That is, a state with no prosecution activity of its own can achieve a deterrence effect if that country has enough neighbors using such prosecutions. In addition, the independent effects of human rights prosecutions on repression are unchanging throughout the models.

\section{Conclusion}

Our findings provide the first quantitative support for the existence of a deterrence effect in the realm of human rights. We conceptualize human rights prosecutions as a type of enforcement of existing human rights law, and our findings are generally supportive of various rationalist theories that posit that an increase in enforcement of law, in the likelihood of sanctions, or in an increase of costs of repression should lead to a decrease in repression. Our finding thus suggest that the increased use of human rights prosecutions and truth commissions around the world can be a valuable policy tool to contribute to lessening repression. Previously, the major findings on the causes of repression all involved macro-level processes over which governments had little control in the short term, including democracy, peace, and economic growth. Our findings suggest that more micro-level policy responses such as prosecutions and truth

\footnotetext{
${ }^{23}$ We define a country i's neighbors using the U.N. sub-regional divisions of the world and included two different variables. First, the number of states having used human rights prosecutions within a state $i$ 's neighbors at year $t$ was used in Model 6a and the number of cumulative prosecution years in state i's neighbors at year $t$ was in Model 6b.
} 
commissions also can have an impact on human rights practices, thus providing policy makers with more viable short term options.

Our findings are also consistent with norms literatures (Risse, et al., 1999) that have stressed that both normative and coercive factors are important for human rights change. Our findings about the impact of truth commissions suggest that it is not merely the likelihood of material punishment that exerts an effect. If it were only the fear of punishment that is producing the deterrence effect, we would not expect the use of truth commissions to be associated with any improvements in human rights. Our findings suggest that any argument about the mechanisms through which human rights prosecutions contribute to improved human rights must combine attention to both their material and normative effects.

In the past, state officials faced few costs for committing human rights violations; now they face more, especially in those countries that have been persistent in carrying out human rights prosecutions. This suggests that there has been an increase in the likelihood of enforcement which, in turn, heightens the expected costs of repression for government officials who make choices about how much repression to use. At the same time, there is no reason to believe that the benefits of repression have increased. So, if the benefits of repression have remained constant and the formal and informal costs of repression have increased, it seems reasonable to suggest that prosecutions deter future human rights violations by increasing the perception of the costs of repression for individual state officials.

By increasing sanctions, human rights prosecutions can modify the strategic context within which security forces operate. For security forces that have already carried out human rights abuses, the strategic landscape is straightforward: it is in their interests to prevent both human rights prosecutions and truth-telling. These are the so-called spoilers, who are often 
willing to go to great lengths to prevent prosecutions. Neither prosecutions nor truth commissions change their calculations very much. Given a choice, spoilers will always prefer no transitional justice at all, preferably guaranteed by an amnesty. They attempt to block domestic prosecutions, through threats, coup attempts, blocked peace processes, and the like. This group has been the main concern of scholars like Snyder and Vinjamuri (2003), who point out the obvious difficulties of such a strategic situation. What they miss, however, is the bigger and longer strategic game that prosecutions can set in motion.

In the longer term, we believe that the actual deterrence of future human rights violations happens through the impact of prosecutions on new generations of military and police officers, and on civilian political leaders. Future military officers may decide that prosecutions have made repression and coups too costly for use in the future. How these leaders calculate costs may vary. Some may interpret the costs of prosecutions mainly in terms of the costs to the reputation and honor of the military or police as an institution; others may calculate the costs in a more individual fashion.

While our research provides evidence that prosecutions work both through their punishment effects and because they communicate norms, this argument cannot be fully tested by our current research. Future qualitative research needs to focus on the reactions of the military, police, and other state officials to prosecutions in order to confirm the exact mechanisms through which human rights prosecutions lead to an improvement in human rights practices. We believe that the economic and political costs of the formal sanctions (lost wages, litigation fees, inability to participate in elections while being prosecuted or in prison, etc) as well as the informal social and political costs that arise from the publicity surrounding the prosecutions (lost of reputation or 
legitimacy, and the resulting loss of political and social support) need to be taken into account in future research.

Complying with human rights norms may require countries to make substantial structural changes in the nature of their domestic institutions. Such changes are not easy to make. Human rights prosecutions are only one of the many factors that can contribute to positive human rights change. While they are not a panacea for human rights problems, they appear to be one form of sanction and normative pressure that can contribute to the institutional and political changes necessary to limit repression. 


\section{Reference}

Abbott, Kenneth, Anne-Marie Slaughter, Robert Keohane, Andrew Moravcsik, and Duncan Snidal. (2000) The Concept of Legalization. International Organization 54:401-19.

Achen, Christopher. (2000) Why Lagged Dependent Variables Can Suppress the Explanatory Power of Other Independent Variables. In Annual Meeting of the Political Methodology. Los Angeles.

Akhaven, Payam. (2001) Beyond Impunity: Can International Criminal Justice Prevent Atrocities? American Journal of International Law 95:7-31.

Alfonsin, Raul. (1996) Democracia Y Consenso. Buenos Aires: Ediciones Corregidor.

Alvarez, Michael R., and Garrett Glasgow. (1999) Two-Stage Estimation of Nonrecursive Choice Model. Political Analysis 8:147-64.

Andenaes, Johannes. (1974) Punishment and Deterrence. Ann Arbor, MI: University of Michigan Press.

Anderson, Christopher J., Patrick M. Regan, and Robert L. Ostergard. (2002) Political Repression and Public Perceptions of Human Rights. Political Research Quarterly $55: 439-56$.

Apodaca, Clair. (2001) Global Economic Patterns and Personal Integrity Rights after the Cold War. International Studies Quarterly 45:587.

Bassiouni, M. Cherif. (1996) The Law of the International Tribunal for the Former Yugoslavia. Irvington-on-Hudson, N.Y.: Transnational Publishers.

—. (2002) Post-Conflict Justice. Ardsley, NY: Transnational Publishers.

Beck, Nathaniel, and Jonathan. N. Katz. (1995) What to Do (and Not to Do) with Time-Series Cross-Section Data. American Journal of Political Science 89:634 47.

Becker, Gary. (1968) Crime and Punishment: An Economic Approach. The Journal of Political Economy 76:169-217.

Berry, Frances Stokes, and William D. Berry. (1990) State Lottery Adoptions as Policy Innovations: An Event History Analysis. American Political Science Review 84:395 415. Blumstein, Alfred, Jacqueline Cohen, and Daniel Nagin. (1978) Deterrence and Incapacitation: Estimating the Effects of Criminal Sanctions on Crime Rates. Washington, D.C.: National Academy of Sciences. 
Brienen, M.E.I., and E.H. Hoegen. (2000) Victims of Crime in 22 European Justice System. Nijmegen, The Netherlands: University of Tilburg.

Bueno de Mesquita, B., George W. Downs, A. M. Smith, and F. M. Cherif. (2005) Thinking inside the Box: A Closer Look at Democracy and Human Rights. International Studies Quarterly 49.

Bueno de Mesquita, Bruce and Lawrence E. Cohen. (1995) Self-Interest, Equity and Crime Control: A Game Theoretic Analysis of Criminal Decisions. Criminology 33:483-517. Cardenas, Sonia. (2007) Conflict and Compliance: State Responses to International Human Rights Pressures. Philadelphia: University of Pennsylvania Press.

Chayes, Abram, and Antonia Chayes. (1993) On Compliance. International Organization 47:175-205.

Cingranelli, David L., and David L. Richards. (2004) The Cingranelli-Richards (Ciri) Human Rights Database Coder Manual.

Damgaard, Ciara. (2008) Individual Criminal Responsibility for Core International Crimes. Springer Publishers.

Davenport, Christian, and David A. Armstrong II. (2004) Democracy and the Violation of Human Rights. American Journal of Political Science 48:538-54.

Downs, George W., David M. Rocke, and Peter N. Barsoom. (1996) Is the Good News About Compliance Good News About Cooperation. International Organization 50:379-406.

Gibney, Mark. (2004) Political Terror Scale.

Goldsmith, Jack Landman, and Stephen D. Krasner. (2003) The Pitfalls of Idealism. Daedalus 132:47-63.

Goldstone, Richard J. (2000) For Humanity: Reflections of a War Crimes Investigator. New Haven: Yale University Press.

Green, Donald P., Soo Yeon Kim, and David H. Yoon. (2001) Dirty Pool. International Organization 55:441-68.

Haas, Peter M. (1992) Introduction: Epistemic Communities and International Policy Coordination. International Organization 46:1 35.

Hafner-Burton, Emilie M. (2005) Right or Robust? The Sensitive Nature of Political Repression in an Era of Globalization. Journal of Peace Research 42:679-98. 
_- (2005) Trading Human Rights: How Preferential Trade Agreements Influence

Government Repression. International Organization 59:593-629.

Hayner, Priscilla B. (2002) Unspeakable Truth: Facing the Challenge of Truth Commission.

New York: Routledge.

Huntington, Samuel P. (1991) The Third Wave: Democratization in the Late Twentieth Century.

Norman: University of Oklahoma Press.

Jelin, Elizabeth, Judy Rein, and Marcial Godoy-Anativia. (2003) State Repression and the

Labors of Memory. Minneapolis, MN: University of Minnesota Press.

Keele, Luke, and Nathan J. Kelly. (2006) Dynamic Models for Dynamic Theories: The Ins and

Outs of Lagged Dependent Variables. Political Analysis 14:1-20.

Keohane, Robert, and Ruth Grant. (2005) Accountability and Abuses of Power in World Politics. American Political Science Review 99:29-43.

Keshk, Omar M. G. (2003) Cdsimeq: A Program to Implement Two-Stage Probit Least Squares. Stata Journal 3:1-11.

Kim, Hunjoon. (2008) Expansion of Transitional Justice Measures: A Comparative Analysis of Its Causes. In Department of Political Science. Minneapolis: University of Minnesota.

Koh, Harold. (1997) Review Essay: Why Do Nations Obey International Law? Yale Law Review 106:2598-659.

Kritz, Neil J. (1995) Transitional Justice: How Emerging Democracies Reckon with Former Regimes. Washington, D.C.: United States Institute of Peace.

Lie, Tove Grete, Helga Malmin Binningsbo, and Scott Gates. (2007) Post-Conflict Justice and Sustainable Peace. In World Bank Policy Research Working Paper: World Bank.

Lutz, Ellen L, and Caitlin Reiger. (2008) Prosecuting Heads of State. Cambridge: Cambridge University Press.

Lutz, Ellen, and Kathryn Sikkink. (2001) The Justice Cascade: The Evolution and Impact of Foreign Human Rights Trials in Latin America. Chicago Journal of International Law $2: 1 \sim 34$.

Macedo, Stephen. (2004) Universal Jurisdiction: National Courts and the Prosecution of Serious Crimes under International Law. Philadelphia: University of Pennsylvania Press.

Matsueda, Ross L., Derek A. Kreager, and David Huizinga. (2006) Deterring Delinquents: A Rational Choice Model of Theft and Violence. American Sociological Review 71:95-122. 
McAdams, James A. (1997) Transitional Justice and the Rule of Law in New Democracies. Notre Dame: University of Notre Dame Press.

McCarthy, Bill. (2002) New Economics of Sociological Criminology. Annual Review of Sociology 28:417-42.

Mendeloff, David. (2004) Truth-Seeking, Truth-Telling, and Postconflict Peacebuilding: Curb the Enthusiasm? International Studies Review 6:355-80.

Méndez, Juan E. (1997) In Defense of Transitional Justice. In Transitional Justice and the Rule of Law in New Democracies, edited by A. James McAdams, pp. 1-26. Notre Dame, IN: University of Notre Dame Press.

Minow, Martha. (1998) Between Vengeance and Forgiveness: Facing History after Genocide and Mass Violence. Boston: Beacon Press.

Mooney, Christopher Z. (2001) Modeling Regional Effects on State Policy Diffusion. Political Research Quarterly 54:103-24.

Nagin, Daniel S. (1998) Criminal Deterrence Research at the Outset of the Twenty-First Century. In Crime and Justice: A Review of Research, edited by M. Tonry, pp. 1-42. Chicago: University of Chicago Press.

Nickell, S. (1981) Biases in Dynamic Models with Fixed Effects. Econometrica 49:1417-26. Office of Justice Programs. (2009) Victims: Role of Victim in Prosecution and Sentencing. In The World Factbook of Criminal Justice Systems, edited by U.S. Department of Justice. Poe, Steven C. (2004) The Decision to Repress: An Integrative Theoretical Approach to the Research on Human Rights and Repression. In Understanding Human Rights Violations: New Systematic Studies, edited by Steven C. Poe and Sabine C. Carey, pp. 16-42: Ashgate Publishing.

Poe, Steven C., Sabine C. Carey, and Tanya C. Vazquez. (2001) How Are These Pictures Different? A Quantitative Comparison of the Us State Department and Amnesty International Human Rights Reports, 1976-1995. Human Rights Quarterly 23:650-77.

Poe, Steven C., and Neal Tate. (1994) Repression of Human Rights to Personal Integrity in the 1980s: A Global Analysis. American Political Science Review 88:853-900.

Poe, Steven C., Neal Tate, and Linda Camp Keith. (1999) Repression of the Human Right to Personal Integrity Revisited. International Studies Quarterly 43:291 313. 
Ratner, Steven, and Jason Abrams. (2001) Accountability for Human Rights Atrocities in International Law: Beyond the Nuremberg Legacy. 2 ed. Oxford: Oxford University Press.

Raustiala, Kal, and Anne-Marie Slaughter. (2002) International Law, International Relations, and Compliance. In Handbook of International Relations, edited by Walter Carlsneaes, Thomas Risse and Beth Simmons, pp. 538-58: Sage.

Richards, David L., R. D. Gelleny, and D. H. Sacko. (2001) Money with a Mean Steak? Foreign Economic Penetration and Government Respect for Human Rights. International Studies Quarterly 45:219-39.

Risse, Thomas, Stephen C. Ropp, and Kathryn Sikkink. (1999) The Power of Human Rights. International Norms and Domestic Change. Cambridge: Cambridge University Press.

Roht-Arriaza, Naomi. (2005) The Pinochet Effect: Transnational Justice in the Age of Human Rights. Philadelphia, PA: University of Pennsylvania Press.

— (1995) Impunity and Human Rights in International Law and Practice. New York, NY: Oxford University Press.

Rummel, Rudolph. (1994) Death by Government. New Brunswick: Transaction.

Simmons, Beth A. (2009) Mobilizing for Human Rights: International Law in Domestic Politics. Cambridge University Press.

Simmons, Beth A. (2000) International Law and State Behavior: Commitment and Compliance in International Monetary Affairs. American Political Science Review 94:819 35.

Snyder, Jack, and Leslie Vinjamuri. (2003) Trial and Errors: Principle and Pragmatism in Strategies of International Justice. International Security 28:5 44.

Sriram, Chandra Lekha. (2003) Revolutions in Accountability: New Approaches to Past Abuses. American University International Law Review 19:310-429.

Thoms, Oskar N. T., James Ron, and Roland Paris. (2008) The Effects of Transitional Justice Mechanisms: A Summary of Empirical Research Findings and Implications for Analysis and Practitioners. Center for International Policy Studies, University of Ottawa.

Walker, Robert W. (2006) Democracy and Human Rights to Personal Integrity: History Matters.

Weissbrodt, David, and Maria Luisa Bartolomei. (1991) The Effectiveness of International Human Rights Pressures: The Case of Argentina 1976-1983. Minnesota Law Review 75. 
Weyland, Kurt. (2005) Theories of Policy Diffusion: Lessons from Latin American Pension Reform. World Politics 57:262-95.

Zanger, Sabine. (2000) A Global Analysis of the Effect of Political Regime Changes on Life Integrity Violations, 1977-93. Journal of Peace Research 37:213 33. 
Appendix 1. List of Countries with Transition

Democratic transitions (68 Countries)

Portugal 1974 ; Greece1974 ; Spain 1975 ; Thailand 1977 1991, 1992 ; Burkina Faso

1977 1980; Peru 1978 1992, 1993 ; Ghana 1978 1981, 1996 ; Dominican Republic 1978 ;

Nigeria 1978 1984, 1998 ; Uganda 1979 1985; Ecuador 1979 ; El Salvador 1979 ; Honduras 1980 ; Bolivia 1982 ; Argentina 1983 ; Turkey 1983 ; Guatemala 1984 ; Brazil 1985 ; Uruguay 1985 ; Haiti 1986 1991, 1994 ; Philippines 1986 ; Republic of Korea 1987 ; Hungary 1988 ; Chile 1988 ; Cambodia 1988 1997; Pakistan 1988 1999 ; Poland 1989 ; Paraguay 1989 ; Czechoslovakia 1989 1992; Panama 1989 ; Romania 1989 ; Benin 1990 ; Nicaragua 1990 ; Comoros 1990 1995, 1996 ; Bulgaria 1990 ; Fiji 1990 ; Mongolia 1990 ; Nepal 1990 2002; Albania 1990 1996, 1997 ; Republic of Congo 1991 1997; Mali 1991 ; Central African Republic 1991 2003; Niger 1991 1996, 1999 ; Bangladesh 1991 ; Madagascar 1991 ; Zambia 1991 1996; Guinea-Bissau 1991 1998, 1999 ; Azerbaijan 1992 ; Guyana 1992 ; South Africa 1992 ; Taiwan 1992 ; Lesotho 1993 1998, 1999 ; Malawi 1993 ; Mexico 1994 ; Mozambique 1994 ; Sierra Leone 1996 1997, 2001 ; Iran 1997 2004; Armenia 1998 ; Indonesia 1998 ; Djibouti 1999 ; Cote d'Ivoire 1999 2002; Senegal 2000 ; Serbia and Montenegro 2000 ; Kenya 2002 ; Macedonia 2002 ; Algeria 2004

Transition from civil war (16 Countries)

Chad 1984 ; Lebanon 1990 ; Ethiopia 1991 ; Angola 1993 ; Rwanda 1994 ; Bosnia and Herzegovina 1995 ; Burundi 1996 ; Comoros 1996 ; Liberia 1996 ; Afghanistan 1996 ; Guinea-Bissau 1999 ; Lesotho 1999 ; Sierra Leone 2001 ; Iraq 2003 ; Democratic Republic of Congo 2003 ; Solomon Island 2003

Transition of state creation (28 Countries)

Namibia 1990 ; Yemen 1990 ; Germany 1990 ; Georgia 1991 ; Croatia 1991 ; Slovenia 1991 ; Serbia and Montenegro 1991 ; Belarus 1991 ; Moldova 1991 ; Azerbaijan 1991 ; Kyrgyzstan 1991 ; Uzbekistan 1991 ; Estonia 1991 ; Latvia 1991 ; Lithuania 1991 ; Tajikistan 1991 ; Macedonia 1991 ; Armenia 1991 ; Turkmenistan 1991 ; Ukraine 1991 ; Kazakhstan 1991 ; Bosnia and Herzegovina 1992 ; Russia 1992 ; Czech Republic 1993 ; Slovakia 1993 ; Ethiopia 1993 ; Eritrea 1993 ; East Timor 2002 
Appendix 2. List of Countries with Human Rights Prosecutions and Truth Commissions

Countries with Transitional Human Rights Prosecutions (48 Countries)

Argentina 1983-90, 1993-04; Benin 1991-93; Bolivia 1983, 1995; Bosnia and Herzegovina 1993-2004; Bulgaria 1993, 1994, 1996; Burundi 1996; Cambodia 2003-04; Chad 2000-03; Chile 1989, 1991-2004; Democratic Republic of Congo 2004; Croatia 1992-2004; Czech Republic 1997, 1998, 2001; East Timor 2002-04; Ecuador 1992-95, 1997; El Salvador 1990-92, 1998; Eritrea 1991, 1993; Ethiopia 1991-92, 1994-2003; Guatemala 1988, 1991-94, 1996-2003; Haiti 1986-87, 1989, 1995-97; Honduras 1992-93, 1996-2002, 2004; Hungary 1993, 1999, 2000-01; Indonesia 2000-04; Iraq 2003-04; Republic of Korea 1996; Lithuania 1997-2002; Macedonia 1993-2004; Malawi 1995; Mali 1991, 1993; Mexico 2002-2004; Namibia 1990; Nicaragua 199296; Niger 1992; Panama 1991-99, 2002, 2004; Paraguay 1989, 1991-92, 1994-99, 2002-04; Peru 1985, 1990, 1993-95, 2001-04; Poland 1990, 1993-94, 1996-2001; Portugal 1980; Romania 1990; Rwanda 1994-2004; Senegal 2000-04; Serbia and Montenegro 2000-04; Sierra Leone 2002-04; Slovenia 1993-04; South Africa 1992; Spain 1982, 2000; Thailand 1998; Turkey 1983; Uruguay 1998-2000, 2002, 2004.

Countries with Truth Commissions (28 Countries)

Argentina 1983; Bolivia 1982; Burundi 1996; Central African Republic 2003; Chad 1990; Chile 1990; Democratic Republic of Congo 2004; East Timor 2002; Ecuador 1996; El Salvador 1992; Germany 1992; Ghana 2002; Guatemala 1997; Haiti 1995; Indonesia 1999; Republic of Korea 2000; Liberia 2003; Nepal 1990; Nigeria1999; Panama 2001; Paraguay 2003; Peru 2001;

Philippines 1986; Serbia and Montenegro 2002; Sierra Leone 2002; South Africa 1995; Uganda 1986; Uruguay 1985 
Appendix 3. Summary Statistics and Data Sources

Summary Statistics

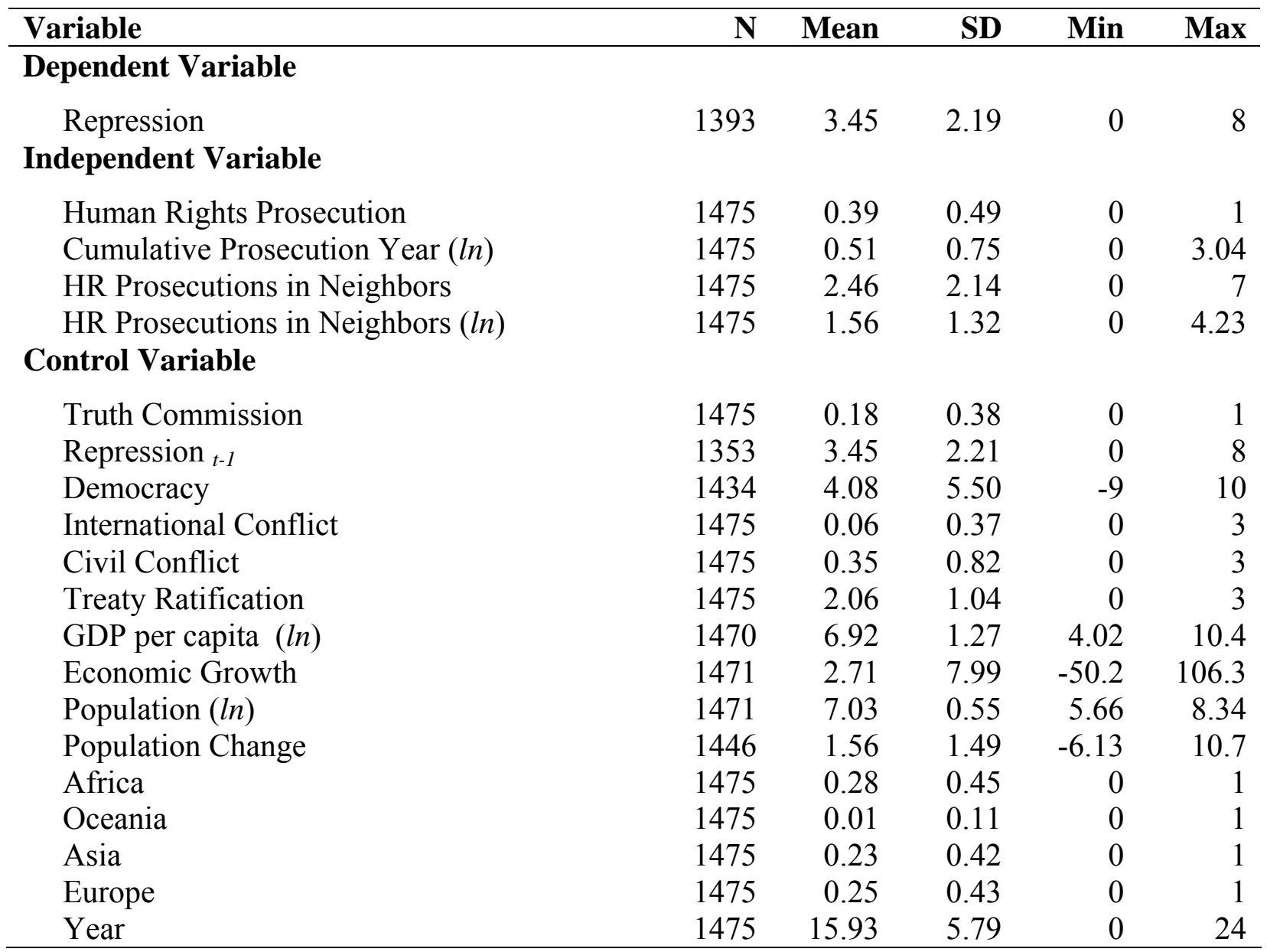

Data Sources

\begin{tabular}{ll}
\hline Variable & Data Sources \\
\hline Repression & CIRI Human Rights Database \\
Democracy & Polity IV Project \\
International and Civil Conflict & PRIO/Uppsala Armed Conflict Dataset \\
Human Rights Treaty Ratification & UN OHCHR \\
$\begin{array}{l}\text { GDP per capita, Annual GDP growth } \\
\text { rate, Population, Annual population } \\
\text { growth rate }\end{array}$ & $\begin{array}{l}\text { UN Common Database (except Taiwan, which } \\
\text { we used the National Statistics data of Taiwan } \\
\text { http://eng.stat.gov.tw/mp.asp?mp=5) }\end{array}$ \\
\hline
\end{tabular}


Table 1: Baseline Models: Impact of Human Rights Prosecutions on Repression

\begin{tabular}{|c|c|c|c|c|c|c|}
\hline & \multicolumn{2}{|c|}{ Model1(Base) } & \multicolumn{2}{|c|}{ Model2a(HRP) } & \multicolumn{2}{|c|}{ Model2b(CHRP) } \\
\hline & $\begin{array}{r}\text { Coef. } \\
\text { (Std.Err.) }\end{array}$ & $\mathrm{p}$-value & $\begin{array}{r}\text { Coef. } \\
\text { (Std.Err.) }\end{array}$ & $\mathrm{p}$-value & $\begin{array}{r}\text { Coef. } \\
\text { (Std.Err.) }\end{array}$ & p-value \\
\hline Prosecution Experience & & & $\begin{array}{r}-0.160 \\
(0.079)\end{array}$ & 0.041 & & \\
\hline Cumulative Prosecution Years $(l n)$ & & & & & $\begin{array}{r}-0.113 \\
(0.055)\end{array}$ & 0.038 \\
\hline Truth Commission Experience & & & $\begin{array}{r}-0.186 \\
(0.098)\end{array}$ & 0.065 & $\begin{array}{r}-0.175 \\
(0.098)\end{array}$ & 0.074 \\
\hline Repression $_{t-1}$ & $\begin{array}{r}0.569 \\
(0.024)\end{array}$ & $<0.001$ & $\begin{array}{r}0.562 \\
(0.024)\end{array}$ & $<0.001$ & $\begin{array}{r}0.562 \\
(0.024)\end{array}$ & $<0.001$ \\
\hline Democracy & $\begin{array}{r}-0.058 \\
(0.008)\end{array}$ & $<0.001$ & $\begin{array}{r}-0.055 \\
(0.008)\end{array}$ & $<0.001$ & $\begin{array}{r}-0.056 \\
(0.008)\end{array}$ & $<0.001$ \\
\hline International Conflict & $\begin{array}{r}-0.162 \\
(0.087)\end{array}$ & 0.063 & $\begin{array}{r}-0.164 \\
(0.086)\end{array}$ & 0.057 & $\begin{array}{r}-0.593 \\
(0.087)\end{array}$ & 0.068 \\
\hline Civil Conflict & $\begin{array}{r}0.458 \\
(0.052)\end{array}$ & $<0.001$ & $\begin{array}{r}0.478 \\
(0.053)\end{array}$ & $<0.001$ & $\begin{array}{r}0.474 \\
(0.052)\end{array}$ & $<0.001$ \\
\hline Human Rights Treaty Ratification & $\begin{array}{r}0.068 \\
(0.046)\end{array}$ & 0.141 & $\begin{array}{r}0.079 \\
(0.047)\end{array}$ & 0.092 & $\begin{array}{r}0.083 \\
(0.047)\end{array}$ & 0.073 \\
\hline GDP per capita $(\ln )$ & $\begin{array}{l}-0.089 \\
(0.041)\end{array}$ & 0.030 & $\begin{array}{r}-0.075 \\
(0.042)\end{array}$ & 0.079 & $\begin{array}{r}-0.078 \\
(0.042)\end{array}$ & 0.064 \\
\hline Annual GDP Growth Rate & $\begin{array}{l}-0.008 \\
(0.006)\end{array}$ & 0.163 & $\begin{array}{r}-0.009 \\
(0.006)\end{array}$ & 0.130 & $\begin{array}{l}-0.009 \\
(0.006)\end{array}$ & 0.130 \\
\hline Population $(\ln )$ & $\begin{array}{r}0.541 \\
(0.075)\end{array}$ & $<0.001$ & $\begin{array}{r}0.563 \\
(0.076)\end{array}$ & $<0.001$ & $\begin{array}{r}0.563 \\
(0.078)\end{array}$ & $<0.001$ \\
\hline Annual Rate of Population Change & $\begin{array}{r}0.013 \\
(0.038)\end{array}$ & 0.731 & $\begin{array}{r}0.026 \\
(0.039)\end{array}$ & 0.501 & $\begin{array}{r}0.028 \\
(0.039)\end{array}$ & 0.474 \\
\hline Africa & $\begin{array}{r}-0.430 \\
(0.136)\end{array}$ & 0.002 & $\begin{array}{r}-0.489 \\
(0.135)\end{array}$ & $<0.001$ & $\begin{array}{r}-0.533 \\
(0.137)\end{array}$ & $<0.001$ \\
\hline Oceania & $\begin{array}{r}-0.481 \\
(0.208)\end{array}$ & 0.021 & $\begin{array}{r}-0.633 \\
(0.212)\end{array}$ & 0.003 & $\begin{array}{r}-0.647 \\
(0.214)\end{array}$ & $<0.001$ \\
\hline Asia & $\begin{array}{r}-0.208 \\
(0.118)\end{array}$ & 0.077 & $\begin{array}{r}-0.312 \\
(0.118)\end{array}$ & 0.008 & $\begin{array}{r}-0.347 \\
(0.122)\end{array}$ & 0.004 \\
\hline Europe & $\begin{array}{l}-0.501 \\
(0.120)\end{array}$ & $<0.001$ & $\begin{array}{r}-0.598 \\
(0.125)\end{array}$ & $<0.001$ & $\begin{array}{l}-0.621 \\
(0.125)\end{array}$ & $<0.001$ \\
\hline Year & $\begin{array}{r}0.010 \\
(0.007)\end{array}$ & 0.154 & $\begin{array}{r}0.014 \\
(0.007)\end{array}$ & 0.050 & $\begin{array}{r}0.017 \\
(0.008)\end{array}$ & 0.030 \\
\hline Constant & $\begin{array}{r}-1.671 \\
(0.493)\end{array}$ & 0.001 & $\begin{array}{r}-1.872 \\
(0.502)\end{array}$ & $<0.001$ & $\begin{array}{l}-1.863 \\
(0.502)\end{array}$ & $<0.001$ \\
\hline $\mathrm{R}^{2}$ & 0.686 & & 0.688 & & 0.688 & \\
\hline$\chi^{2}$ & 3509.76 & & 3519.46 & & 3520.71 & \\
\hline $\mathrm{N}$ & 1314 & & 1314 & & 1314 & \\
\hline Number of states & 95 & & 95 & & 95 & \\
\hline
\end{tabular}

Note: Table entries are OLS regression estimates corrected for panel-specific autocorrelation and p-values in Stata 9.2/SE. Panel corrected standard errors are included in the parentheses. 
Table 2: Fixed-effects Models: Impact of Human Rights Prosecution on Repression

\begin{tabular}{|c|c|c|c|c|}
\hline & \multicolumn{2}{|c|}{ Model3a(HRP) } & \multicolumn{2}{|c|}{ Model3b(CHRP) } \\
\hline & $\begin{array}{r}\text { Coef. } \\
\text { (Std.Err.) }\end{array}$ & p-value & $\begin{array}{r}\text { Coef. } \\
\text { (Std.Err.) }\end{array}$ & p-value \\
\hline Prosecution Experience & $\begin{array}{r}-0.425 \\
(0.153)\end{array}$ & 0.006 & & \\
\hline Cumulative Prosecution Years $(l n)$ & & & $\begin{array}{r}-0.383 \\
(0.102)\end{array}$ & $<0.001$ \\
\hline Truth Commission Experience & $\begin{array}{r}-0.514 \\
(0.175)\end{array}$ & 0.003 & $\begin{array}{r}-0.445 \\
(0.176)\end{array}$ & 0.012 \\
\hline Repression $_{t-1}$ & $\begin{array}{r}0.279 \\
(0.026)\end{array}$ & $<0.001$ & $\begin{array}{r}0.272 \\
(0.026)\end{array}$ & $<0.001$ \\
\hline Democracy & $\begin{array}{r}-0.048 \\
(0.013)\end{array}$ & $<0.001$ & $\begin{array}{r}-0.047 \\
(0.013)\end{array}$ & $<0.001$ \\
\hline International Conflict & $\begin{array}{r}-0.345 \\
(0.096)\end{array}$ & $<0.001$ & $\begin{array}{r}-0.333 \\
(0.096)\end{array}$ & 0.001 \\
\hline Civil Conflict & $\begin{array}{r}0.535 \\
(0.069)\end{array}$ & $<0.001$ & $\begin{array}{r}0.524 \\
(0.069)\end{array}$ & $<0.001$ \\
\hline Human Rights Treaty Ratification & $\begin{array}{r}0.154 \\
(0.068)\end{array}$ & 0.024 & $\begin{array}{r}0.133 \\
(0.068)\end{array}$ & 0.052 \\
\hline GDP per capita $(l n)$ & $\begin{array}{r}-0.043 \\
(0.141)\end{array}$ & 0.761 & $\begin{array}{r}-0.004 \\
(0.141)\end{array}$ & 0.979 \\
\hline Annual GDP Growth Rate & $\begin{array}{r}-0.016 \\
(0.005)\end{array}$ & 0.003 & $\begin{array}{r}-0.016 \\
(0.005)\end{array}$ & 0.003 \\
\hline Population $(l n)$ & $\begin{array}{r}-3.793 \\
(1.434)\end{array}$ & 0.008 & $\begin{array}{r}-3.555 \\
(1.428)\end{array}$ & 0.013 \\
\hline Annual Rate of Population Change & $\begin{array}{r}-0.049 \\
(0.052)\end{array}$ & 0.337 & $\begin{array}{r}-0.046 \\
(0.051)\end{array}$ & 0.370 \\
\hline Year & $\begin{array}{r}0.038 \\
(0.015)\end{array}$ & 0.011 & $\begin{array}{r}0.044 \\
(0.015)\end{array}$ & 0.003 \\
\hline Constant & $\begin{array}{r}29.051 \\
(10.358) \\
\end{array}$ & 0.005 & $\begin{array}{r}27.082 \\
(10.315) \\
\end{array}$ & 0.009 \\
\hline $\mathrm{R}^{2}$ & 0.255 & & 0.259 & \\
\hline $\mathrm{N}$ & 1314 & & 1314 & \\
\hline Number of states & 95 & & 95 & \\
\hline
\end{tabular}

Note: Table entries are fixed-effects regression estimates with standard errors in parentheses and p-values in Stata $9.2 / \mathrm{SE}$. 
Table 3: Impact of Human Rights Prosecution on Repression(Two-Stage Estimations)

\begin{tabular}{|c|c|c|c|c|}
\hline & \multicolumn{2}{|c|}{$\begin{array}{l}\text { HRP instrumented } \\
\text { Model4a(2SPLS) }\end{array}$} & \multicolumn{2}{|c|}{$\begin{array}{l}\text { CHRP instrumented } \\
\text { Model4b(G2SLS) }\end{array}$} \\
\hline & $\begin{array}{r}\text { Coef. } \\
\text { (Std.Err.) } \\
\end{array}$ & p-value & $\begin{array}{r}\text { Coef. } \\
\text { (Std.Err.) } \\
\end{array}$ & p-value \\
\hline Prosecution Experience (instrumented) & $\begin{array}{r}-0.209 \\
(0.079)\end{array}$ & 0.009 & & \\
\hline Cumulative Prosecution Years (instumented $l n$ ) & & & $\begin{array}{r}-0.476 \\
(0.184)\end{array}$ & 0.010 \\
\hline Truth Commission Experience & $\begin{array}{r}-0.139 \\
(0.099) \\
\end{array}$ & 0.165 & $\begin{array}{r}-0.103 \\
(0.112) \\
\end{array}$ & 0.036 \\
\hline$\chi^{2}$ & 173.19 & & 2273.20 & \\
\hline $\mathrm{N}$ & 1281 & & 1281 & \\
\hline Number of states & 94 & & 94 & \\
\hline
\end{tabular}

Note: Table entries are OLS regression estimates corrected for panel-specific autocorrelation and p-values in Stata 9.2/SE. Panel corrected standard errors are included in the parentheses. To conserve space, we do not report the control variables or constant terms for the regressions. 
Table 4: Impact of Human Rights Prosecutions on Repression under Civil Conflict Situations

\begin{tabular}{|c|c|c|c|c|}
\hline & \multicolumn{2}{|c|}{ Model5a(HRP) } & \multicolumn{2}{|c|}{ Model5b(CHRP) } \\
\hline & $\begin{array}{r}\text { Coef. } \\
\text { (Std.Err.) }\end{array}$ & p-value & $\begin{array}{r}\text { Coef. } \\
\text { (Std.Err.) }\end{array}$ & $\mathrm{p}$-value \\
\hline Prosecution Experience & $\begin{array}{r}-0.166 \\
(0.087)\end{array}$ & 0.055 & & \\
\hline Civil War $\times$ Prosecution Experience & $\begin{array}{r}-0.059 \\
(0.090)\end{array}$ & 0.509 & & \\
\hline Civil War Transition $\times$ Prosecution Experience & $\begin{array}{r}0.139 \\
(0.329)\end{array}$ & 0.674 & & \\
\hline Cumulative Prosecution Years $(l n)$ & & & $\begin{array}{r}-0.113 \\
(0.058)\end{array}$ & 0.049 \\
\hline Civil War $\times$ Cum. Prosecution Years & & & $\begin{array}{r}-0.159 \\
(0.076)\end{array}$ & 0.038 \\
\hline Civil War Transition $\times$ Cum. Prosecution Years & & & $\begin{array}{r}0.168 \\
(0.188)\end{array}$ & 0.369 \\
\hline Truth Commission Experience & $\begin{array}{r}-0.215 \\
(0.117)\end{array}$ & 0.067 & $\begin{array}{r}-0.215 \\
(0.118)\end{array}$ & 0.068 \\
\hline Civil War $\times$ Truth Commission & $\begin{array}{r}-0.064 \\
(0.106)\end{array}$ & 0.549 & $\begin{array}{l}-0.085 \\
(0.106)\end{array}$ & 0.422 \\
\hline Civil War Transition $\times$ Truth Commission & $\begin{array}{r}0.282 \\
(0.354)\end{array}$ & 0.425 & $\begin{array}{r}0.244 \\
(0.340)\end{array}$ & 0.474 \\
\hline Civil Conflict & $\begin{array}{r}0.501 \\
(0.072)\end{array}$ & $<0.001$ & $\begin{array}{r}0.542 \\
(0.069)\end{array}$ & $<0.001$ \\
\hline Transition from Civil War & $\begin{array}{r}0.296 \\
(0.153) \\
\end{array}$ & 0.153 & $\begin{array}{r}0.325 \\
(0.208)\end{array}$ & 0.119 \\
\hline $\mathrm{R}^{2}$ & 0.691 & & 0.692 & \\
\hline$\chi^{2}$ & 3606.59 & & 3595.06 & \\
\hline $\mathrm{N}$ & 1314 & & 1314 & \\
\hline Number of states & 95 & & 95 & \\
\hline
\end{tabular}

Note: Table entries are OLS regression estimates corrected for panel-specific autocorrelation and p-values in Stata 9.2/SE. Panel corrected standard errors are included in the parentheses. To conserve space, we do not report the control variables or constant terms for the regressions.

Table 5: The Effect of Prosecutions on Repression under Various Civil War-Related Situations

\begin{tabular}{lcccc}
\hline & \multicolumn{3}{c}{ Effect of HR Prosecutions } \\
& Coef. & Std.Err. & p-value & $\begin{array}{c}\text { Number of Cases } \\
\text { (Country-Years) }\end{array}$ \\
\hline No Civil War Transition with No Civil Wars & -0.16 & 0.09 & 0.005 & 1106 \\
No Civil War Transition with Minor Civil Wars & -0.23 & 0.10 & 0.029 & 61 \\
& & 0.26 & 0.179 & 57 \\
& & & & \\
No Civil War Transition with Major Civil Wars & -0.35 & & & \\
& -0.03 & 0.33 & 0.933 & 104 \\
Civil War Transition with No Civil Wars & -0.09 & 0.31 & 0.775 & 32 \\
Civil War Transition with Minor Civil Wars & -0.21 & 0.34 & 0.544 & 19 \\
\hline
\end{tabular}

Note: Cell report conditional coefficients and standard errors for effect of prosecution on repression drawn from Model 3a. 
Table 6: Impact of Human Rights Prosecutions in Neighboring Countries on Repression

\begin{tabular}{lrrrr}
\hline & \multicolumn{3}{c}{ Model6a(HRP) } & \multicolumn{2}{c}{ Model6b(CHRP) } \\
& Coef. & p-value & $\begin{array}{r}\text { Coef. } \\
\text { (Std.Err.) }\end{array}$ & p-value \\
& & & & \\
Prosecution Experience & -0.160 & 0.041 & & \\
& $(0.079)$ & & & \\
HR Prosecutions in Neighbors & -0.043 & 0.068 & & \\
& $(0.023)$ & & -0.103 & 0.062 \\
Cumulative Prosecution Years $(l n)$ & & & $(0.055)$ & \\
& & & -0.093 & 0.034 \\
Cumulative Prosecution Years in Neighbors $(l n)$ & & & $(0.044)$ & \\
& & -0.205 & 0.037 \\
Truth Commission Experience & -0.204 & 0.036 & $(0.098)$ & \\
& $(0.097)$ & & 0.689 & \\
\hline $\mathrm{R}^{2}$ & 0.689 & & 3518.41 & \\
$\chi^{2}$ & 3515.35 & & 1314 & \\
$\mathrm{~N}$ & 1314 & & 95 & \\
Number of states & 95 & & & \\
\hline
\end{tabular}

Note: Table entries are OLS regression estimates corrected for panel-specific autocorrelation and p-values in Stata 9.2/SE. Panel corrected standard errors are included in the parentheses. To conserve space, we do not report the control variables or constant terms for the regressions. 